TAO, Vol. 14, No. 3, 321-333, September 2003

\title{
Late Quaternary Deep-Water Circulation in the South China Sea
}

\author{
Hui-Ling $\operatorname{Lin}^{1, *}$
}

(Manuscript received 27 August 2002, in final form 29 May 2003)

\begin{abstract}
A suite of four new benthic foraminiferal (Cibicidoides wuellerstorfi) stable carbon isotope records produced from South China Sea (SCS) sediment cores ranging in water depth from 1515 and $3766 \mathrm{~m}$ are used here to evaluate deep-water circulation in the SCS over the last complete glacialinterglacial cycle (i.e., the last 200 kyrs). A common pattern of benthic $\delta^{13} \mathrm{C}$ variations is observed between cores, with pronounced $\delta^{13} \mathrm{C}$ depletions recorded during glacial periods and $\delta^{13} \mathrm{C}$ enrichments during interglacials. The overall similarity of $\delta^{13} \mathrm{C}$ values between sites indicates a homogeneous water mass below $1500 \mathrm{~m}$ in the SCS basin through time, except for the interval between 120 and $65 \mathrm{ka}$. Temporal changes in ventilation and exchange between the SCS and western Pacific are indicated by comparison with records from the Ontong Java Plateau (OJP). The presence of Pacific Intermediate Water can be inferred based on the bathymetric gradient of $\delta^{13} \mathrm{C}$ between SCS and $\mathrm{OJP}\left(\Delta \delta^{13} \mathrm{C}\right)$. The $\Delta \delta^{13} \mathrm{C}$ patterns do not appear to be correlated with glacial-interglacial cycles. However, the $\Delta \delta^{18} \mathrm{O}$ is greater in warm intervals (late MIS 4 and early MIS 3; MIS 1) than during cold intervals.
\end{abstract}

(Key words: Benthic foraminiferal stable isotope records, South China sea)

\section{INTRODUCTION}

The distribution of $\delta^{13} \mathrm{C}$ of $\Sigma \mathrm{CO}_{2}$ in the surface ocean is largely controlled by biological activity and air-sea exchange, whereas seawater $\delta^{13} \mathrm{C}$ below the permanent thermocline is largely a function of deep circulation and the effects of remineralization of sinking organic material (Kroopnick 1980, 1985). Foraminiferal $\delta^{13} \mathrm{C}$ measurements made on benthic taxa were the first applied to paleo-reconstructions, specifically to infer past variability in deepwater circulation patterns. This is because the processes that control deepwater $\delta^{13} \mathrm{C}$ are less

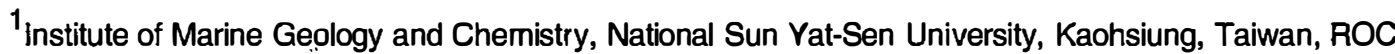

${ }^{*}$ Corresponding author address: Hui-Ling Lin, Institute of Marine Geology and Chemistry, National Sun Vat-Sen University, Kaohsiung, Taiwan 804; E-mail: hllin @ mail.nsysu.edu.tw 
complicated than those at the surface. In recent decades, a large number of investigations have utilized $\delta^{13} \mathrm{C}$ records of benthic foraminifera as deepwater paleoceanographic tracers (e.g., Broecker 1982; Shackleton et al. 1983; Duplessy et al. 1988; Oppo and Fairbanks 1987; Oppo et al. 1990; Mix et al. 1991; Mackensen et al. 1993; Bickert and Wefer 1999). In most of these studies, the benthic foraminifer species Cibicidoides wuellerstorfi and related taxa have been measured since they appear to calcify their tests with respect to $\delta^{13} \mathrm{C}$ composition close to that of the ambient bottom-water $\mathrm{\Sigma CO}_{2}$ (e.g., Zahn et al. 1986). Subsequently, the "Mackensen effect" was proposed to explain the additional depletion of $\delta^{13} \mathrm{C}$ that can occur as a result of high surface productivity and the additional input of ${ }^{12} \mathrm{C}$ from the decomposition of organic matter on the sea floor (Mackensen et al. 1993).

Deep-water circulation is closely related to climate change (e.g., Mix et al. 1991; Oppo et al. 1997; McIntyre et al. 1999). A longstanding paleoceanographic question is whether, during glacial periods, the North Pacific may have been a source of deep water (e.g., Berger 1987; Curry et al. 1988; Duplessy et al. 1988; Ohkouchi et al. 1994; Jian et al. 1997; Keigwin 1998). Today, deep water formation in the North Pacific is suppressed by the low salinity of the surface waters. Unfortunately, relevant research into potential sources of North Pacific Deep Water is restricted by poor carbonate preservation in most of the Pacific Ocean.

As a marginal basin along the western edge of the Pacific, the South China Sea (SCS) is separated from the western Pacific and Indian Oceans by a series of shallow sills that range in water depth from 36 to $2200 \mathrm{~m}$. The SCS is characterized by sedimentation rates than are an order of magnitude higher than found in most of the Pacific and carbonate sediments are widespread. The SCS thus offers a special opportunity for reconstructing deepwater paleoceanography in the Pacific. However, only a few studies to date have addressed glacial deep circulation in the SCS based on benthic foraminifer assemblages (e.g., Jian and Wang 1997; Jian et al. 1999) and the isotopic compositions of benthic foraminifera (e.g., Winn et al. 1992; Wang et al. 1999). The present study focuses on benthic $\delta^{13} \mathrm{C}$ records from different water depths in the SCS basin and on their comparison with the western equatorial Pacific record to infer past variations in the ventilation of deep water.

\section{MATERIALS AND METHODS}

A total of four benthic stable isotope records were generated for this study. The locations of cores that were used are indicated on the bathymetric map (Fig. 1), and information regarding the geographic coordinates, water depth and core length are listed in Table 1. Benthic foraminifers of the species Cibicidoides wuellerstorfi were analyzed both at the Leibniz Laboratory of Kiel University and at the University of California, Davis. Results are presented relative to the standard PDB-scale and are reported with a precision better than $0.07 \%$ for $\delta^{18} \mathrm{O}$ and $0.06 \%$ for $\delta^{13} \mathrm{C}$.

\section{RESULTS AND DISCUSSION}

\subsection{Distribution of $\delta^{18} \mathrm{O}$ and $\delta^{13} \mathrm{C}$ in the Water Column}

Before beginning the downcore study, the isotopic compositions of $C$. wuellerstorfi from 


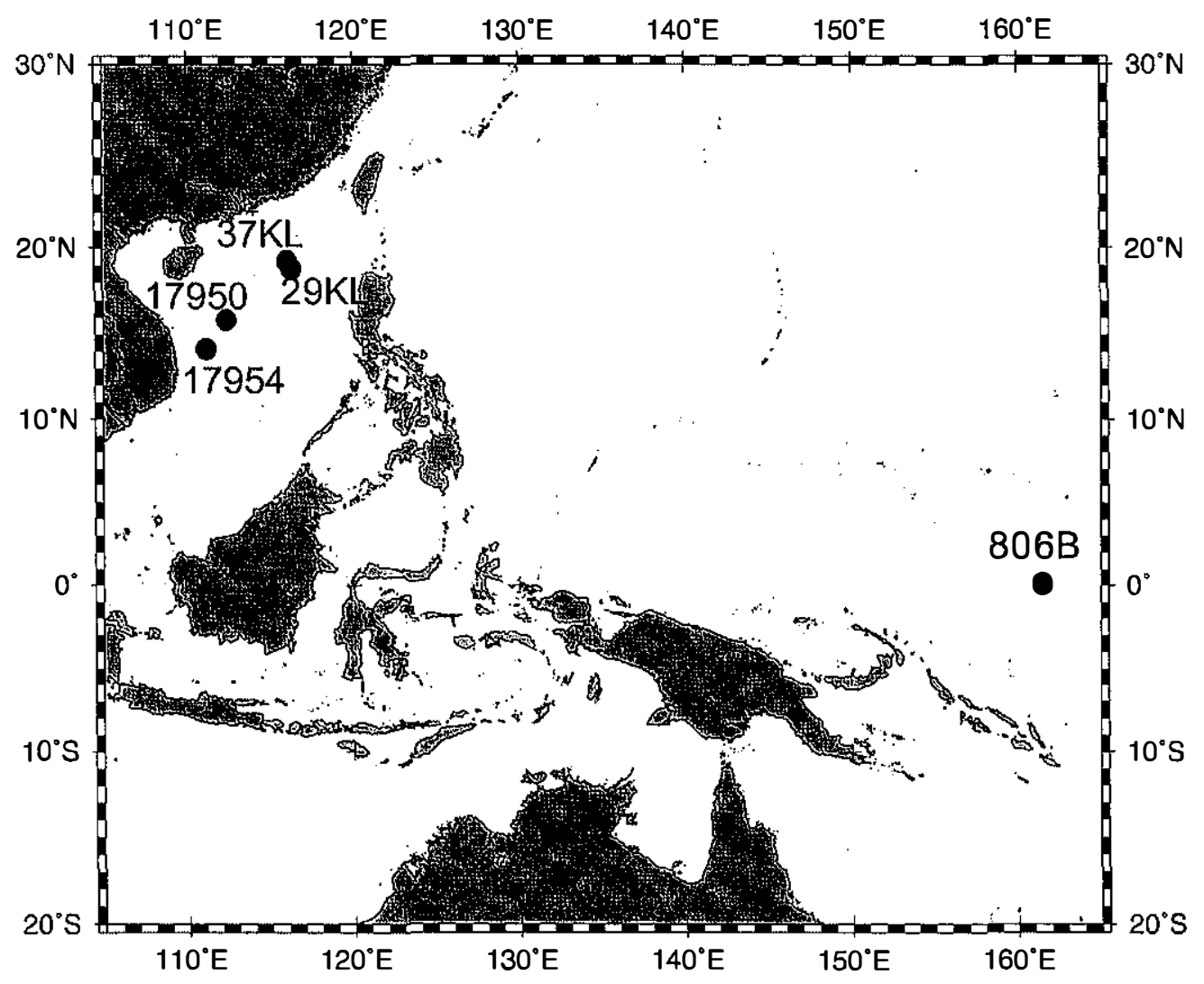

Fig. 1. Location map showing position of Cores 17950, 17954, SO50-29 Kl, SO50-37 KL, and of Ocean Drilling Program (ODP) Hole 806B.

Table 1. Location, water depth, and core recovery for cores discussed in this study

\begin{tabular}{rccccc}
\hline Core I.D. & Latitude & Longitude & Depth & Recovery & Data \\
& $(\mathrm{N})$ & $(\mathrm{E})$ & $(\mathrm{m})$ & $(\mathrm{cm})$ & measurement \\
SO95-17954 & $14^{\circ} 47.8^{\prime}$ & $111^{\circ} 31.5^{\prime}$ & 1515 & 1152 & Kiel \\
SO95-17950 & $16^{\circ} 05.6^{\prime}$ & $112^{\circ} 53.8^{\prime}$ & 1868 & 991 & UC Davis $^{\prime}$ \\
SO50-37KL & $18^{\circ} 54.0^{\prime}$ & $115^{\circ} 46.0^{\prime}$ & 2695 & 851 & Kiel $^{\text {a }}$ \\
SO50-29KL & $18^{\circ} 24.0^{\prime}$ & $115^{\circ} 59.0^{\prime}$ & 3766 & 993 & Kiel $^{\text {a }}$ \\
\hline
\end{tabular}

a. from Winn et al. (1992) 


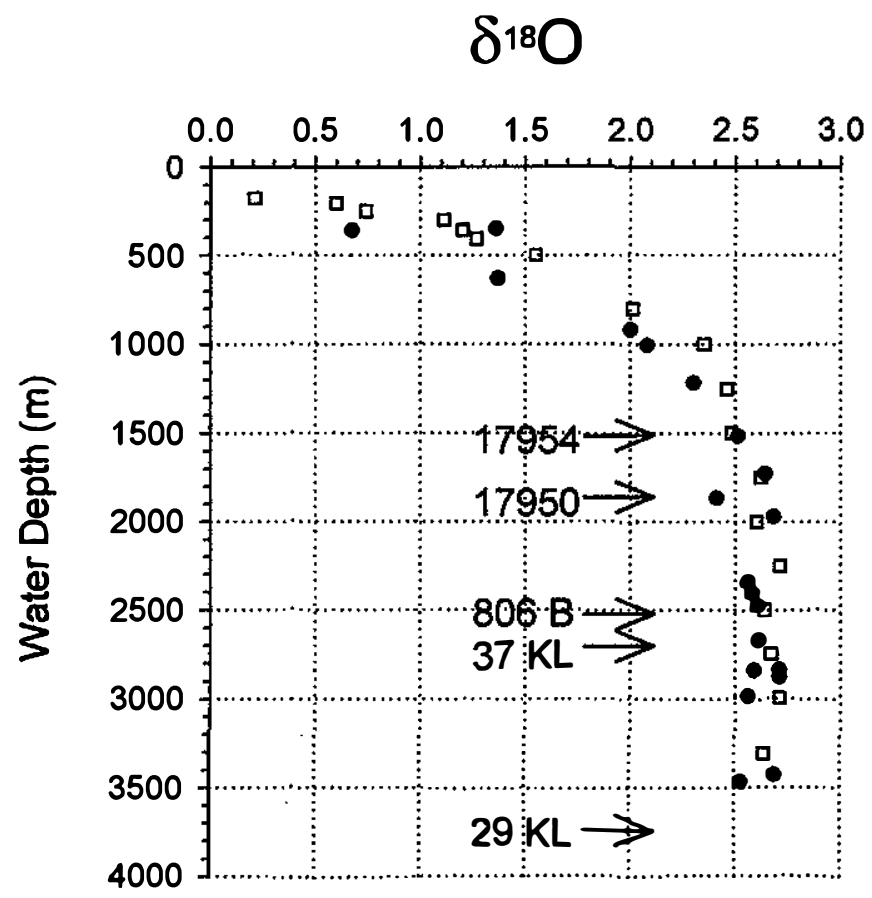

- C. wuellerstorii

- Estimated based on $\delta^{18} \mathrm{O}_{\text {water }}$

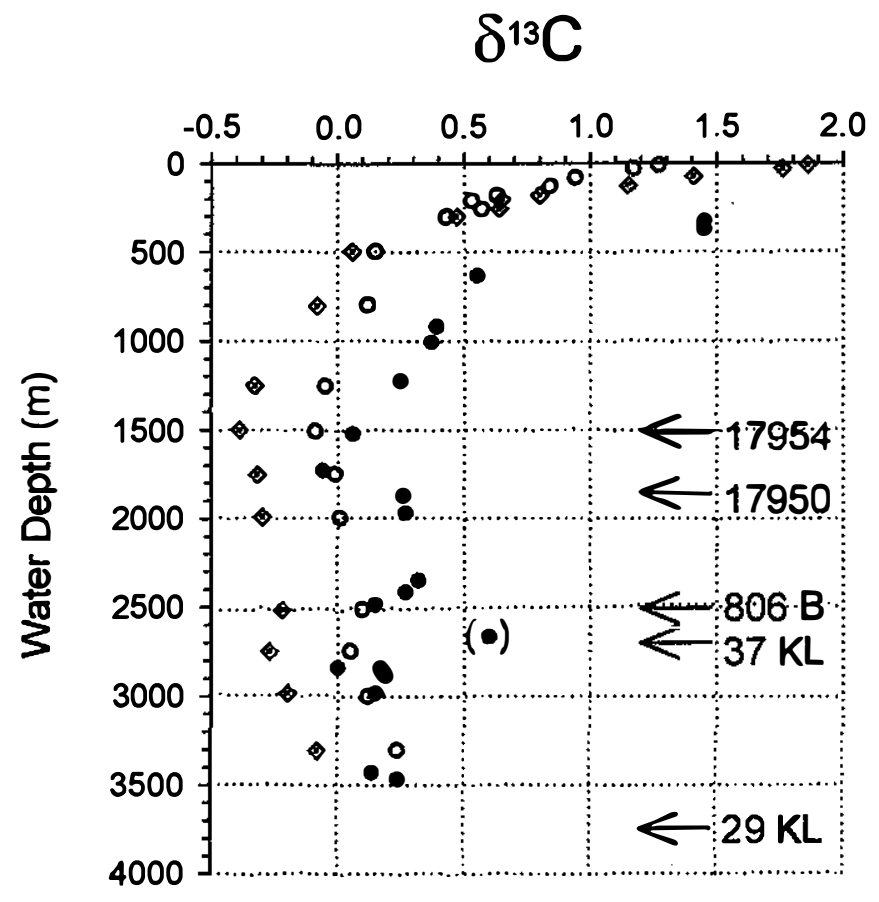

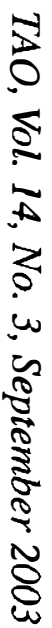

- $\delta^{13} \mathrm{C}_{\Sigma \mathrm{CO}_{2}}$ (Lin et al. 1999)

- Estimated based on $\delta^{13} \mathrm{C}_{\Sigma \mathrm{CO}_{2}}$

Fig. 2. Vertical profiles of $\delta^{18} \mathrm{O}-\delta^{13} \mathrm{C}$ in the northern South China Sea shown in comparison to the $C$. wuellerstorfi coretop data of Grothmann (1996). 
Recent coretops were compared with the distribution of $\delta^{18} \mathrm{O}$ and $\delta^{13} \mathrm{C}$ in the water column (Fig. 2). The $C$. wuellerstorfi coretop data were taken from Grothmann (1996) while the water column data are based on our own measurements. Bemis et al. (1998) concluded that Cibicidoides precipitates its shell close to oxygen isotopic equilibrium with seawater and that the expected equilibrium values can be estimated by: $\mathrm{T}\left({ }^{\circ} \mathrm{C}\right)=16.5( \pm 0.2)-4.80( \pm 0.16)^{*}$ $(\delta \mathrm{c}-\delta \mathrm{w})$. The estimated $\delta^{18} \mathrm{O}$ plotted on Fig. 2 were calculated based on the above equation and using field data for temperature and $\delta^{18} \mathrm{O}$ (i.e., $\delta \mathrm{w}$ in equation; open squares on Fig. 2) from the northeast SCS (unpublished data; Station E in Lin et al. 1999). Overall, the coretop data are in good agreement with the calculated $\delta^{18} \mathrm{O}$ equilibrium values, supporting the basis for the following discussion.

The $\delta{ }^{13} \mathrm{C}$ compositions of $C$. wuellerstorfi from all coretops are close to the measured $\delta^{13} \mathrm{C}$ values of ambient seawater $\sum \mathrm{CO}_{2}$ (open circles on Fig. 2; Lin et al. 1999). Interestingly, the coretop $\delta^{13} \mathrm{C}$ values are closer to the direct measurements of $\Sigma \mathrm{CO}_{2}$ than to the calculated values of calcite $\delta^{13} \mathrm{C}$ in equilibrium (dotted diamonds on Fig. 2). The calculated values of calcite $\delta^{13} \dot{\mathrm{C}}$ are based on Grossman (1998), as modified from Epstein et al. (1953): $\delta^{13} \mathrm{C}=$ $\left(\delta^{13} \mathrm{C}\right.$ of $\left.\sum \mathrm{CO}_{2}\right)+[10.51-(2980 / \mathrm{Tw}+273)]$. The $\delta^{13} \mathrm{C}$ of $C$. wuellerstorfi from coretops fall well within the range of $\delta^{13} \mathrm{C}$ in the water column at depths below $1500 \mathrm{~m}$, except for the data point enclosed in parentheses which comes from a location near the mouth of the Pearl River. The similarity between coretop $\delta^{13} \mathrm{C}$ of $C$. wuellerstorfi and $\delta^{13} \mathrm{C}_{\mathrm{\Sigma CO} 2}$ below $1500 \mathrm{~m}$ water depth endorses the feasibility of using $C$. wuellerstorfi $\delta^{13} \mathrm{C}$ for the downcore records.

\section{$3.2 \delta^{18} \mathrm{O}$ and $\delta^{13} \mathrm{C}$ Stratigraphy}

Downcore variations in the $\delta^{18} \mathrm{O}$ and $\delta^{13} \mathrm{C}$ compositions of $C$. wuellerstorfi for the four study cores are plotted in Figs. 3 and 4 in ascending order of water depth, together with the record from ODP Hole 806B for reference. ODP Hole 806B was drilled on the Ontong Java Plateau (OJP) in the western equatorial Pacific $\left(0^{\circ} 19.1^{\prime} \mathrm{N}, 159^{\circ} 21.7^{\prime} \mathrm{E}\right)$ and is currently bathed by Pacific Deep Water (Craig et al. 1981). The chronology for individual cores is based on their $\delta^{18} \mathrm{O}$ stratigraphy and the vertical and horizontal axes are scaled the same for easy comparison. Cores SO50-37 and -29 KL did not penetrate marine isotope stage 5e (MIS 5e; Winn et al. 1992) and hence do not span the complete last glacial-interglacial cycle.

Coretop values of benthic $\delta^{18} \mathrm{O}$ from the four SCS cores appear to reflect bottom water temperature; the deeper the core is situated, the heavier the $\delta^{18} \mathrm{O}$ that is recorded (Fig. 3). For example, there is a systematic 0.2 0.4\% shift between Cores 17954 and 17950 throughout the two records. Furthermore, the range of $\delta^{18} \mathrm{O}$ variation in Core 17950 is very similar to that of ODP Site 806B, indicating a similarity of the watermasses at these two locations. While there is no significant observed difference in $\delta^{18} \mathrm{O}$ amplitude between the last glacial maximum (LGM) and Holocene for all individual cores, the $\delta^{18} \mathrm{O}$ gradient $\left(\Delta \delta^{18} \mathrm{O}_{1-\mathrm{D}}\right)$ between the intermediate (ODP 806B) and deep water (SO5-37 and -29 KL) cores, however, is quite different through the glacial cycles. The $\Delta \delta^{18} \mathrm{O}_{1-D}$ is generally reduced in cold intervals relative to warm periods, i.e., it is $<0.2 \%$ during the LGM in contrast to $>0.5 \%$ in the Holocene (MIS 1).

Overall, the downcore $\delta^{13} \mathrm{C}$ rends show isotopically heavier $\delta^{13} \mathrm{C}$ values during inter- 


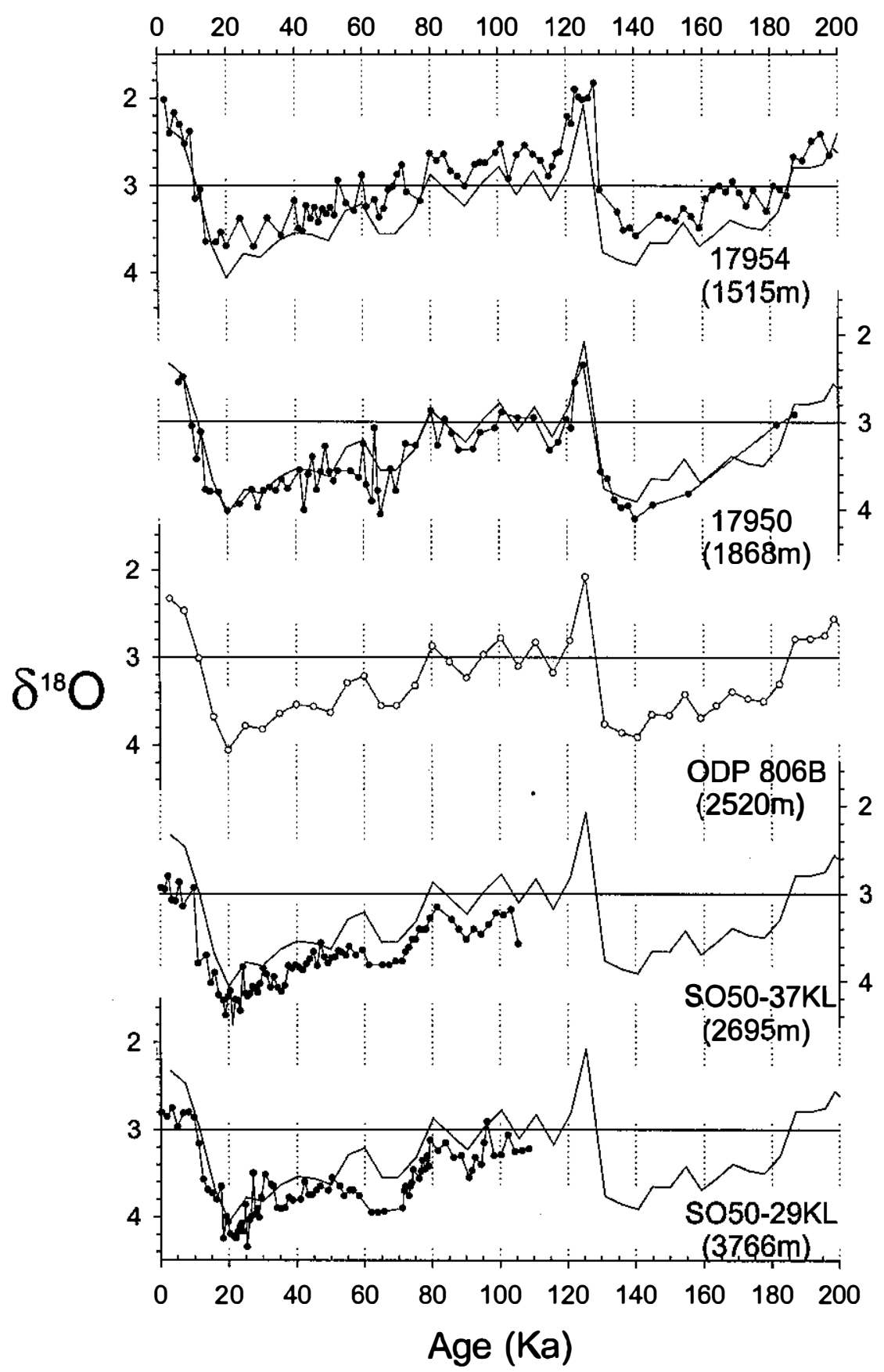

Fig. 3. Time-series of the stable oxygen $\left(\delta^{18} \mathrm{O}\right)$ isotope composition of $C$. wuellerstorfi for the four SCS cores and for ODP Hole 806B plotted in order of coring water depth. Superimposed on the individual SCS core records is the record of ODP Hole 806B for comparison. 


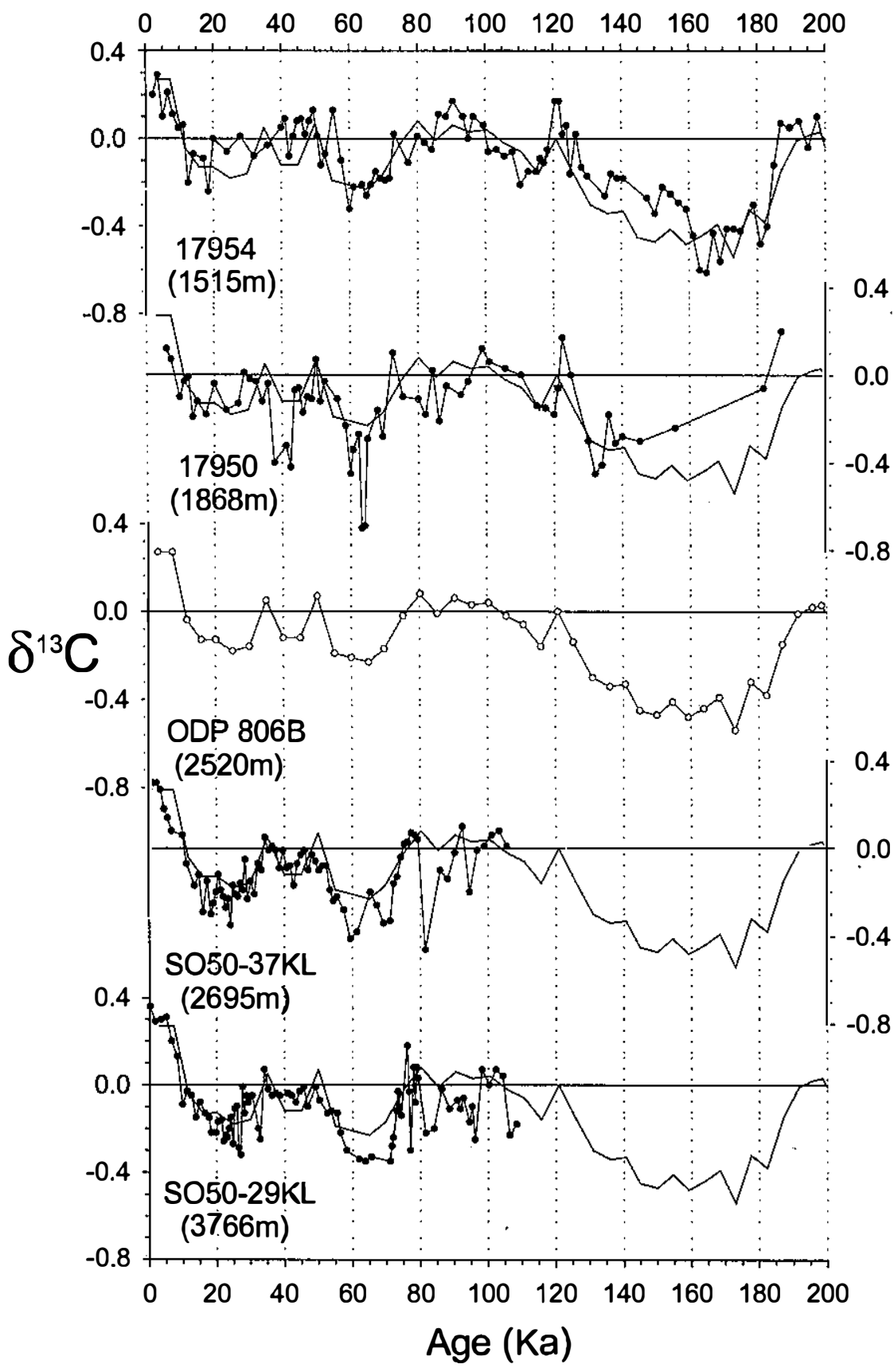

Fig. 4. Time-series of the stable carbon $\left(\delta^{13} \mathrm{C}\right)$ isotope composition of $C$. wuellerstorfi for the four SCS cores and for ODP Hole 806B plotted in order of coring water depth. Superimposed on the individual SCS core records is the record of ODP Hole 806B for comparison. 
glacials (warm periods) and lighter $\delta^{13} \mathrm{C}$ values during glacials (cool periods; Fig. 4). However, the magnitude of the $\delta^{13} \mathrm{C}$ depletion during glacials decreases progressively from MIS 6 to MIS2. The amplitude of glacial-interglacial $\delta^{13} \mathrm{C}$ fluctuations from deeper cores (i.e., $>2000$ $\mathrm{m}$; Cores SO50-37 and $-29 \mathrm{KL} ; 0.7 \% 0$ ) are generally larger than those from shallower cores, which display changes more in line with the global average $\delta^{13} \mathrm{C}$ shift of $0.46 \%$ (Curry et al. 1988). The hydrographic gradient reflected by the $\Delta \delta^{18} \mathrm{O}_{\mathrm{I}-\mathrm{D}}$ contrasts discussed above was not found in the $\delta^{13} \mathrm{C}$ records. Instead, the $\Delta \delta^{13} \mathrm{C}$ gradient between the intermediate (ODP Site 806B) and deep water (SO50-37 and -29 KL) cores are more or less consistent $(0.2 \sim 0.3 \%$ ) throughout the glacial cycles. One interesting feature is the pronounced but intermittent $\delta^{13} \mathrm{C}$ depletion exhibited in the deeper sites (>2000 m; Cores SO50-37 and -29 KL) during the Last Interglacial (MIS 5), especially the conspicuous $\delta^{13} \mathrm{C}$ low near the end of MIS 5 that seems to be contemporaneous between cores. In addition, the two highly $\delta^{13} \mathrm{C}$-depleted intervals around 65 60 ka and $40 \mathrm{ka}$ recorded in Core 17950 are also seen in the records of the other cores, though with much weaker signals (Fig. 4). The $\delta^{13} \mathrm{C}$ event around $65 \sim 60 \mathrm{ka}$ has also been documented at one other core from the southern margin of the basin (Core 17961; Wang et al. 1999 ) as an abrupt and pronounced $0.5 \%$ drop. Unfortunately, due to the relatively short core lengths of SO50-37 and -29KL, a complete deep water $\delta^{13} \mathrm{C}$ record from the SCS for MIS5 was not possible in this study.

\subsection{Sill Depth in the Luzon Strait}

As a marginal basin surrounded by shallow sills that are mostly $<50 \mathrm{~m}$ in water depth, deep water in the SCS is largely derived from the western Pacific through the deep passage at Luzon Strait between Taiwan and Luzon. The depth of the deepest channel along the Luzon Strait, however, has been variously reported as shallow as $1900 \mathrm{~m}$ (Broecker et al. 1986) to as deep as 2500 2600 $\mathrm{m}$ (Jian and Wang 1997; Wang 1999). Hence, the depth of the controlling sill adopted in this study is critical to any further discussion since we are comparing our SCS data with a record from the western Pacific that comes from a depth of $2520 \mathrm{~m}$ (ODP Site 806B; Bickert and Wefer 1999). Hydrographic observations were used as the primary basis for our determination of sill depth for the following discussion. Water properies in the SCS, including potential temperature and salinity, remain fairly constant below $2000 \mathrm{~m}$ and are very similar to those in the western Pacific (Gong et al. 1992). A sill depth of 2000 to $2200 \mathrm{~m}$ was therefore taken as the critical threshold separating the SCS from the western Pacific in this study. Thus, both the $\delta^{18} \mathrm{O}$ and $\delta^{13} \mathrm{C}$ signals from cores deeper than $2200 \mathrm{~m}$ (i.e., SO50-37 and $-29 \mathrm{KL}$ ) in the SCS are expected to be analogous to those from the western Pacific. ODP Hole 806B from the OJP hence serves as an appropriate reference for comparison and for the following discussion.

\subsection{Deep-water Circulation in the South China Sea}

The benthic $\delta^{18} \mathrm{O}$ and $\delta^{13} \mathrm{C}$ records from the SCS are best considered in the context of data from the western Pacific. Figure 5 illustrates the covariance patterns of benthic $\delta^{18} \mathrm{O}$ and $\delta^{13} \mathrm{C}$ values from the suite of cores. The upper panel contains data from the cores shallower 

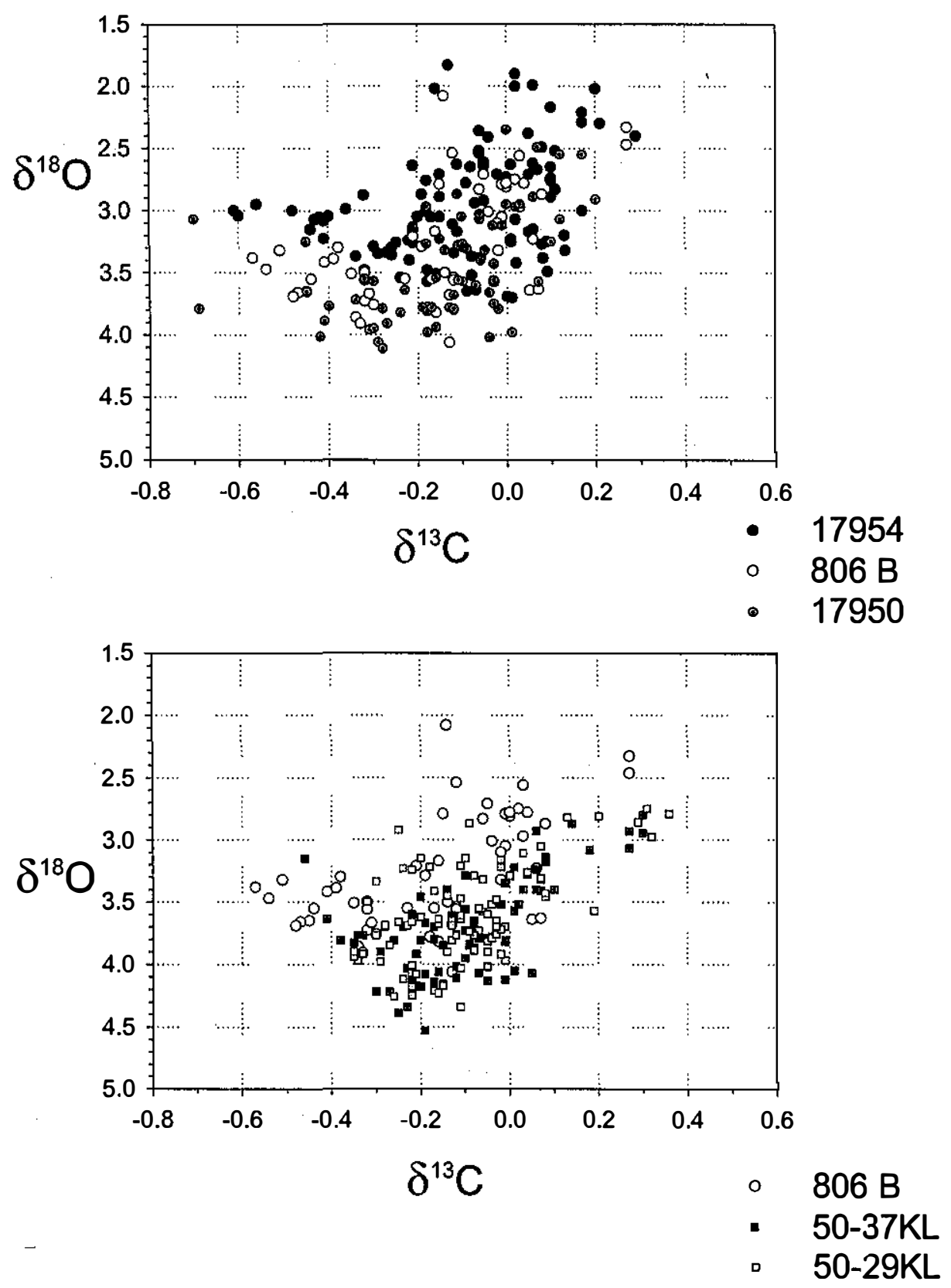

Fig. 5. Crossplots of benthic $\delta^{18} \mathrm{O}$ and $\delta^{13} \mathrm{C}$ values from the set of cores to examine covariance relationships. The upper panel includes cores from depth shallower than ODP Hole 806B (17954 and 17950) while the lower panel shows cores deeper ( 37 and $29 \mathrm{KL}$ ) than ODP Hole 806B. In both panels, the data from ODP Hole 806B are shown for comparison. 
than the OJP site (17954 and 17950) while the lower panel shows cores deeper than Hole 806B (37 and $29 \mathrm{KL}$ ). The $\delta^{18} \mathrm{O}$ and $\delta^{13} \mathrm{C}$ data from Hole 806B are shown in both panels for comparison. In general, the distribution patterns of $\delta^{18} \mathrm{O}-\delta^{13} \mathrm{C}$ in the upper panel are very similar, particularly between Cores 17950 and 806B. The data for Core 17954 on this panel are shifted towards lighter values by about $0.4 \%$ relative to the other two cores with respect to $\delta^{18} \mathrm{O}$. This shift can be ascribed to a temperature effect resulting from the shallower water depth of Core 17954. In contrast, there is no clear offset in the $\delta^{13} \mathrm{C}$ data between cores; indeed, the similar range of $\delta^{13} \mathrm{C}$ values among the three cores implies a close relationship between the SCS and the western Pacific in terms of ventilation in the mid-depth range of the controlling sills. Deep water renewal in the SCS has been reported to be rapid based on radiocarbon measurements (Broecker et al. 1986, 1988), with a residence time estimated between 40 and 120 years according to calculations of influxes and basin volume (Gong et al. 1992).

Even though deep water of the SCS below the sill depth of the Luzon Strait is provided by the western Pacific, significant deviations in $\delta^{18} \mathrm{O}-\delta^{13} \mathrm{C}$ between the deep SCS and the OJP are clearly revealed in the lower panel of Fig. 5. Both the $\delta^{18} \mathrm{O}$ and $\delta^{13} \mathrm{C}$ of benthic foraminifers in the deep part of the SCS ( 37 and $29 \mathrm{KL}$ ) are enriched relative to those from the OJP. The SCS enrichment of $\delta^{18} \mathrm{O}(\sim 0.4 \%)$ relative to the OJP indicates slightly cooler deep water in the SCS during glacial time (about $1.9^{\circ} \mathrm{C}$, according to the equation of Bemis et al. 1998), not counting for possible salinity effects. A $1.1^{\circ} \mathrm{C}$ cooling of deep water has been suggested as an upper limit in the western equatorial Pacific (Birchfield 1987; Bickert et al. 1993). The additional glacial cooling in the SCS compared with the open ocean is possibly due to the enclosed-basin hydrographic setting induced by lowered sea level during the glacial (Wang 1999).

Wang et al. (1999) have inferred that an extreme oxygen-minimum layer developed near the southern margin of the SCS during glacials based on low epibenthic $\delta^{13} \mathrm{C}$ signals, leading to an estuarine stratification of the surface water. However, data from this study do not seem to support this hypothesis. A different $\Delta \delta^{13} \mathrm{C}_{\mathrm{I}-\mathrm{D}}$ pattern between glacial periods would be expected if the deepwater circulation mode changed substantially in response to climate. The large negative $\delta^{13} \mathrm{C}$ excursions observed in the SCS between 70 and $60 \mathrm{ka}$ (late MIS 4 and early MIS 3 for deep cores) relative to ODP Hole 806B were not repeated in the SCS during the LGM. It therefore seems more likely that these depleted events can be attributed to the "Mackensen effect" as a result of episodes of increased surface productivity (Mackensen et al. 1995). On the other hand, some evidence for different deepwater masses in the SCS can perhaps be found in the different $\Delta \delta^{18} \mathrm{O}_{\mathrm{I} \text {.D }}$ observed between glacials and interglacials.

Acknowledgements The author is grateful for the kind assistance of Prof. H. Spero at UC Davis, Prof. C. H. Wang at the Academic Sinica, and the late Prof. L. Wang of Hokkaido University (previously at Kiel University) for stable isotope analyses. Prof. L. Peterson at RSMAS/University of Miami is thanked for helping to make the English more readable. This study was supported by grants from the National Science Council (89-2611-M-110-027-ODP) and the DAAD in Germany (1996). 


\section{REFERENCES}

Bemis, B. E., H. J. Spero, J. Bijma, and D. W. Lea, 1998: Reevaluation of the oxygen isotopic composition of planktonic foraminifera: Experimental results and revised paleotemperature equations. Paleoceanography, 13, 150-160.

Berger, W., 1987: Ocean ventilation during the last 12,000 years: Hypothesis of counterpoint deep water production. Mar. Geol., 78, 1-10.

Birchfield, G. E., 1987: Changes in deep-ocean water and temperature from the last glacial maximum. Paleoceanography, 2, 431-442.

Bickert, T., and G. Wefer, 1999: South Atlantic and benthic foraminifer $\delta^{13} \mathrm{C}$ deviations: Implications for reconstructing the Late Quaternary deep-water circulation. Deep-Sea Res., 46, 437-452.

Broecker, W. S., 1982: Glacial to interglacial changes in ocean chemistry. Prog. Oceanog., 11, 151-197.

Broecker, W. S., M. Andree, G. Bonani, W. Wolfli, M. Klas, A. C. Mix, and H. Oeschger, 1988: Comparison between radiocarbon ages obtained on coexisting planktonic foraminifera. Paleoceanography, 3, 647-657.

Broecker, W. S., W. C. Patzert, J. R. Toggweiler, and M. Stuvier, 1986: Hydrography, chemistry, and radioisotopes in the southeast Asian basin. J. Geophys. Res, 91, 1434514354.

Craig, H., W. S. Broecker, and D. Spencer, 1981: GEOSECS Pacific Expedition (Vol. 3): Washington (U.S. Govt. Printing Office).

Curry. W. B., J. C. Duplessy, L. D. Labeyrie, and N. J. Shackleton, 1988: Quaternary deepwater circulation changes in the distribution of $\delta^{13} \mathrm{C}$ of deep water $\Sigma \mathrm{CO}_{2}$ between the last glaciation and the Holocene. Paleoceanography, 3, 317-342.

Duplessy, J. C., N. J. Shackleton, R. G. Fairbanks, L. Labeyrie, D. Oppo, and N. Kallel, 1988: Deep water source variations during the last climatic variations and their impact on the global deep water circulation. Paleoceanography, 3, 343-360.

Epstein, S., R. Buchsbaum, H. A. Lowenstam, and H. C. Huey, 1953: Revised carbonatewater isotopic temperature scale. Geol. Soc. Am. Bull., 64, 1315-1326.

Gong, G. C., K. K. Liu, C. T. Liu, and S. C. Pai, 1992: The chemical hydrography of the South China Sea west of Luzon and a comparison with the West Philippine Sea. TAO, 3, 587602.

Grossman, E. L., 1982: Stable isotopes in live benthic formainfera from the Southern California Borderland, Ph.D. dissertation, 164 pp., Univ. of Southern Calif., Los Angeles.

Grothmann, A., 1996: Rezente Verbreitungsmuster vulkanischer, terrigener und biogener Komponenten und stablier Kohlenstoff- und Sauerstoff-Isotope in Sedimenten der Südchina-See. M. Sc. Thesis, Kiel University.

Jian, Z., and L. Wang, 1997: Late Quaternary benthic foraminifera and deep-water paleoceanography in the South China Sea. Marine Micropaleontology, 32, 127-154.

Jian, Z., L. Wang, M. Kienast, M. Sarnthein, W. Kuhnt, H. L. Lin, and P. Wang, 1999: Benthic foraminiferal Paleoceanography of the South China Sea over the last 40,000 years. 
Marine Geology, 156, 159-186.

Keigwin, L. D., 1998: Glacial-age hydrography of the far northwest Pacific Ocean. Paleoceanography, 13, 323-339.

Kroopnick, P. M., 1980: The distribution of ${ }^{13} \mathrm{C}$ in the Atlantic Ocean. Earth and Planet Science Letters, 49, 469-484.

Kroopnick, P. M., 1985: The distribution of ${ }^{13} \mathrm{C}$ of $\mathrm{SCO}_{2}$ in the world Oceans. Deep-Sea Research, 32, 57-84.

Lin, H. L., L. W. Wang, C. H. Wang, and G. C. Gong, 1999: Vertical distribution of $\delta^{13} \mathrm{C}$ of dissolved inorganic carbon in the Northeastern South China Sea. Deep-Sea Res., 46, 757-775.

Mackensen, A., H. W. Hubberten, T. Bickert, G. Fischer, and D. K. Fütterer, 1993: The $\delta^{13} \mathrm{C}$ in benthic foraminiferal tests of Fontbotia wuellerstorfi (Schwager) relative to the $\delta^{13} \mathrm{C}$ of dissolved inorganic carbon in southern Ocean deep water: Implications for glacial ocean circulation models. Paleoceanography, 8, 587-610.

McIntyre, K., A. C. Ravelo, and M. L. Delaney, 1999: North Atlantic Intermediate Waters in the late Pliocene to early Pleistocene. Paleoceanography, 14, 324-335.

Mix, A. C., N. G. Pisias, R. Zahn, W. Rugh, C. Lopez, and K. Nelson, 1991: Carbon 13 in Pacific deep and intermediate waters, 0-370 ka: Implications for ocean circulation and Pleistocene $\mathrm{CO}_{2}$. Paleoceanography, 6, 205-226.

Ohkouchi, N., H. Kawahata, M. Murayama, M. Okada, T. Nakamura, and A. Taira, 1994: Was deep water formed in the North Pacific during the Late Quaternary? Cadmium evidence from the northwest Pacific. Earth Planet. Sci. Lett., 124, 185-194.

Oppo, D. W., and R. G. Fairbanks, 1987: Variability in the deep and intermediate water circulation of the Atlantic Ocean during the past 25,000 years: Northern hemisphere modulation of the southern Ocean. Earth Planet. Sci. Lett., 86, 1-15.

Oppo, D. W., R. G. Fairbanks, A. L. Gordon, and N. J. Shackleton, 1990: Late Pleistocene southern ocean $\delta^{13} \mathrm{C}$ variabililty. Paleoceanography, 5, 43-54.

Oppo, D. W., M. Horowitz, and S. J. Lehman, 1997: Marine core evidence for reduced deep water production during Termination II followed by a relative stable substage $5 \mathrm{e}$ (Eemian).Paleoceanography, 12, 51-63.

Shackleton, N. J., M. A. Hall., J. Line, and S. Cang, 1983: Carbon isotope data in core V19-30 confirm reduced carbon dioxide in the ice age atmosphere. Nature, 306, 319-322.

Wang, L., M. Sarnthein, H. Erlenkeuser, J. Grimalt, P. Grootes, S. Heilig, E. Ivanova, M. Kienast, C. Pelejero, and U. Pflaumann, 1999: East Asian monsoon climate during the Late Pleistocene: High-resolution sediment records from the South China Sea. Marine Geology, 156, 245-284.

Wang, P., Response of Western Pacific marginal seas to glacial cycles: Paleoceanographic and sedimentological features. Marine Geology, 156, 5-40.

Winn, K., L. Zheng, H. Erlenkeuser, and P. Stoffers, 1992: Oxygen/carbon isotopes and paleoproductivity in the South China Sea during the past 110,000 years: In: Jin, X., Kudrass, H. R., and G. Pautot (Eds.), Marine Geology and Geophysics of the South China Sea, Proceedings of the Symposium on the Recent Contributions to the Geological History of the South China Sea, China Ocean Press, Hangzhou, p. 154-166. 
Zahn, R., K. Winn, and M. Sarnthein, 1986: Benthic foraminiferal $\delta^{13} \mathrm{C}$ and accumulation rates of organic carbon: Uvigerina peregrina group and Cibicidoides wuellerstorfi. Paleoceanography, 1, 27-42. 